OPEN ACCESS

Edited by:

Miguel Angel Prieto Lage,

University of Vigo, Spain

Reviewed by:

Javier Echave Álvarez,

University of Vigo, Spain

María Carpena Rodríguez,

Polytechnic Institute of Bragança (IPB), Portugal

Antía González Pereira,

University of Vigo, Spain

Paula García Oliveira,

Polytechnic Institute of Bragança (IPB), Portugal

*Correspondence:

Lei Wang

wleileiyu@163.com

Specialty section:

This article was submitted to

Food Chemistry,

a section of the journal

Frontiers in Nutrition

Received: 09 March 2021

Accepted: 12 May 2021

Published: 07 June 2021

Citation:

Sun X, Sun Y, Li Y, Wu Q and Wang L

(2021) Identification and Characterization of the Seed Storage

Proteins and Related Genes of Cannabis sativa $L$.

Front. Nutr. 8:678421

doi: 10.3389/fnut.2021.678421

\section{Identification and Characterization of the Seed Storage Proteins and Related Genes of Cannabis sativa L.}

\author{
Xin Sun, Yao Sun, Yao Li, Qiong Wu and Lei Wang* \\ Department of Biotechnology, Institute of Advanced Technology, Heilongjiang Academy of Sciences, Harbin, China
}

Hemp (Cannabis sativa L.) seed is emerging as a novel source of plant protein owing to its rich protein content and reasonable nutritional structure. In the current study, the storage proteins of hemp seed were extracted using different methods. The modified Osborne method yielded maximum extraction of the hemp seed storage proteins, while degreasing had little effect on the hemp seed protein (HSP) extraction. Protein identification results revealed that $11 \mathrm{~S}$ globulin (edestin) was the most abundant protein in hemp seed, and the molecular weights of the two subunits of this protein were $\sim 35$ and $20 \mathrm{kDa}$, respectively. The second most abundant protein was 2S albumin (Cs2S), with a molecular weight of $\sim 14-15 \mathrm{kDa}$. The least abundant protein was $7 \mathrm{~S}$ vicilin-like protein (Cs7S), with a molecular weight of $\sim 47 \mathrm{kDa}$. Subsequently, gene families encoding these three storage protein classes, including three genes for edestin, two for Cs2S, and one for Cs7S, were cloned and then analyzed for amino acid composition and structure. The three edestins were different in their amino acid sequences and calculated molecular weights. The analysis of coding sequences revealed a higher percentage of similarity (62.7\%) between Edestin1 and Edestin3, while the similarity decreased significantly to 57\% between Edestin1 and Edestin2, and 58\% between Edestin2 and Edestin3. The calculated protein molecular weight was the highest for the protein encoded by Edestin1 and the smallest for the protein encoded by Edestin2. All three edestins were rich in arginine, while Edestin3 had a higher methionine content relative to that in the other two, which proved that Edestin3 had a better nutritional value. Cs2S and Cs7S were different from those reported in previous studies. Therefore, it could be inferred that amino acid composition varies with different hemp cultivars. The current research brought significant theoretical advance in illuminating the understanding of hemp seed storage protein and would have significance for future research on improving the nutritional quality of hemp seed and developing bioactive peptides.

Keywords: Cannabis sativa, seed storage protein, albumin, edestin, vicilin-like protein

\section{INTRODUCTION}

Hemp (Cannabis sativa L.) has been widely used as a fiber source for a long time, with the earliest history records from $8,000 \mathrm{BC}$ when people used its fiber to make rope for pottery (1). Industrial hemp (C. sativa L. supsp. sativa), generally refer to hemp, has $<0.3 \%$ of tetrahydrocannabinol (THC), a higher plant height, and the main parts used are seeds and fiber (2). Owing to its low 
THC content, industrial hemp is unable to stimulate human nerves, therefore, has a potential to be grown as a safe crop (3).

Besides fiber, hemp seeds, which commonly refer to seeds from industrial hemp, is a high-quality source of protein and oil (4). Hemp seeds contain $\sim 20-25 \%$ protein, $25-35 \%$ oil, $20-$ $30 \%$ carbohydrates, and $10 \%$ fiber $(5,6)$. The hemp seed protein (HSP) is mainly composed of three types of protein, namely, $11 \mathrm{~S}$ globulin (edestin), 2S albumin, and $7 \mathrm{~S}$ vicilin-like protein, which account for $\sim 60-80 \%, 13 \%$, and $5 \%$ of total seed protein, respectively (7-9). Research on nutritional composition of seeds from different hemp cultivars has proved that the contents of protein exhibit significant variations among different cultivars, and are influenced by agronomic conditions (temperature and total rainfall), and mainly genotype. Analysis of variance revealed that the genotypic variance accounted for $52.4 \%$ of the total variation in the protein content. The effect of growing year was also significant. It was also found that geography, climatic conditions, and local agronomic factors may affect hemp seed nutritional composition (10). The amount of protein in hemp seeds was higher than or similar to other protein-rich products, such as quinoa (13.0\%), buckwheat seeds (27.8\%), and linseeds $(20.9 \%)(11,12)$. Due to its high protein content, inclusion of hemp seed can increase the protein content of food products. It was reported that about $38 \%$ increase in protein content was observed when replacing up to $20 \%$ of wheat flour with hemp seed flour to make bread (13), hence, hemp seed can be considered a good protein source.

The nutritional quality of a protein is determined by its amino acid composition, digestibility, and bioavailability. HSP is rich in all 9 essential amino acids, in amounts that are sufficient for 2 to 5 -year-old children as recommended by FAO/WHO $(14,15)$. The most abundant amino acid of HSP is glutamic acid (3.74$4.58 \%$ ) followed by arginine (2.28-3.10\%). Glutamate can be used as a neurotransmitter in brain, and although not an essential amino acid, arginine is a dietary precursor for the formation of nitric oxide (NO), therefore it is with beneficial cardiovascular properties and has been linked to optimal immune function and muscle repair (16). In addition, HSP provides high quantities of sulfur-containing amino acids (methionine and cystine), which may serve as a nutritional tool to boost the antioxidant capacity of human body (15). The proportion of essential amino acids to the total amino acids (E/T) for HSP was $45.16 \%$, which significantly higher than that of soybean proteins $(41.72 \%)$, suggesting that HSP has more nutritional amino acid pattern than that of soybean proteins (12). Furthermore, HSP does not contain trypsin inhibitor, which is considered one of the most important antinutritional factors and is found in many species of graminaceous, cruciferous and leguminosae, rendering the former easier to digest and absorb in the human body $(3,17,18)$.

It was found that the solubility of HSP at acidic $\mathrm{pH}$ was lower than that of soy proteins, which may be due to the formation of covalent disulphide bonds among individual molecules of edestin, resulting in insoluble protein aggregates, it was also found that the denaturation temperature of HSP was $92^{\circ} \mathrm{C}(6$, 19). Investigating on the in vitro digestibility of HSP showed that untreated HSP was much more digestible compared to soy proteins (14). Research on in vivo digestibility of HSP showed that it exhibited a high degree of digestibility compared to other plant protein sources, such as canola meal and borage meal, as they contained highly digestible amino acids $(8,20)$. Overall, nutritionally, the HSP is highly digestible and has a better amino acid composition compared to several other plant proteins. It can be considered a good viable, vegetable-based protein source for human diet (4). Although nutritional value of plant proteins is lightly lower than that of animal proteins, they have certain benefits (21-24). Specially, plant protein resources are more abundant, cheaper, and more accessible in relative that of animal proteins. In addition, the hydrolysates of plant protein have unique physiological functions $(22,25-$ 29). After digestion with different proteases, the hydrolysates of HSP were demonstrated to exhibit various physiological activities in vitro as well as in vivo, with hemp proteins short-chain peptides such as WVYY and PSLPA exhibiting antioxidant ability, GVLY and LGV exhibiting anti-hypertension ability, and the hydrolysates exhibiting antiproliferative and hypocholesterolemic activities (30-36).

Acid-precipitation-alkali extraction method was used in most studies to extracted HSP, since it was easy to implement. However, protein denaturation is inevitable owing to the addition of a strong alkali during the extraction process, which may affect the results of the subsequent experiments. Osborne fractionation method can extract proteins of different solubility, because of its mild extraction conditions, it might be a better method for extracting HSP. In addition, there are commercial kits that claim can extract seed proteins gently and completely. In the present study, the two methods and protein extraction kit were used for extracting the hemp seed storage proteins, the extraction results of them were compared.

Although hemp seed storage proteins have been wellcharacterized at the biochemical level, the knowledge of gene families encoding these seed storage proteins and their structures remains to be limited. Amino acid composition is an important factor which determined nutritional quality of a protein. Proteins belonging to the same protein family may have different amino acid compositions, and the amino acid composition can be obtained from their gene sequences. Hence, study of genes encoding proteins is helpful to the study of the nutritional quality of proteins. Moreover, samples used in researches were mainly obtained from Europe and a few from Yunnan of China, and there is no detailed research on hemp plant samples from other regions, especially those in northern China. Cultivated species from different regions have different genotypes, which is the main factor that influences protein content, as described earlier. There is no research on the HSP structures from different regional varieties. The present study was aimed to fill this gap by extracting seed storage proteins from hemp plants grown in northern China, characterizing and analyzing the corresponding genes, which would bring significant theoretical advance in illuminating the understanding of nutritional quality of HSP and the study on its protein structure would be conducive to the identification of its active peptides. The present research would serve as a reference for the development of high-quality plant proteins and the application of active peptides in food and medicine. 


\section{MATERIALS AND METHODS}

\section{Materials and Reagents}

Fresh seeds of $C$. sativa var. Longma 5, which was a commercial variety from Heilongjiang Province, China (one of the major provinces in hemp cultivation), were obtained from $\mathrm{Ms}$. $\mathrm{Mu}$ (General manager of Heilongjiang Heike Technology Co. Ltd). The chemicals including $\mathrm{NaOH}$ and $\mathrm{NaCl}$ were purchased from Hongyan Co. (Tianjin, China); $\mathrm{NH}_{4} \mathrm{HCO}_{3}$, acetonitrile, dithiothreitol, acetonitrile, formic acid, RNase-free DNase I and PBS buffer were purchased from Thermo Fisher Scientific (San Jose, CA, USA); n-hexane was purchased from Aladdin Co. (Shanghai, China); $\mathrm{HCl}$ was purchased from Kermel Co.(Tianjin, China); KOD enzyme was purchased from Toyobo Co. (Osaka, Japan); pGEM-T plasmid was purchased from Takara Co. (Kyoto, Japan); 5X protein loading buffer was purchased from Beyotime Co. (Shanghai, China); Coomassie brilliant blue R-250 was purchased from Solarbio Co. (Beijing, China). The kits including protein extraction kit and RNA extraction kit were purchased from Solarbio Co. (Beijing, China) and Tiangen Co. (Beijing, China), respectively. All reagents used in the study were of analytical grade or higher purity.

\section{Preparation of Hemp Protein Isolate (HPI)}

The proteins were extracted from hemp seeds using the method of Tang with a few modifications (37). In the present work, both defatted and raw hemp seeds were used and three different methods were selected and compared to observe the effect of degreasing and different methods on the SDS results of protein extraction. First, the hemp seeds were ground to powder using liquid nitrogen, followed by dispersion of seed powder in nhexane in a ratio of $1: 4(w / v)$ and then stirring for $3 \mathrm{~h}$ at room temperature. Next, the semi-defatted hemp flour was added into $\mathrm{n}$-hexane in a ratio of $1: 6(w / v)$ and stirred overnight; after that, the hemp flour was put in fume hood to remove traces of n-hexane at room temperature. Subsequently, the defatted hemp flour was dissolved in deionized water in a ratio of $1: 20(w / v)$, the $\mathrm{pH}$ of the mixture was adjusted to 9.0-10.0 using $1 \mathrm{M} \mathrm{NaOH}$, and then the mixture was stirred for $4 \mathrm{~h}$ at room temperature. The mixture was subjected to centrifugation at $8,000 \mathrm{~g}$ for $30 \mathrm{~min}$ at $20^{\circ} \mathrm{C}$. The supernatant was recovered, its $\mathrm{pH}$ was adjusted to 5.0 using $1 \mathrm{M} \mathrm{HCl}$, and after allowing it to stand for $10-20 \mathrm{~min}$, the precipitate was collected through centrifugation at $8,000 \mathrm{~g}$ for $30 \mathrm{~min}$ at $20^{\circ} \mathrm{C}$. The precipitate was washed three times with deionized water and resuspended in deionized water, with the $\mathrm{pH}$ adjusted to 7.0. The suspension was freeze-dried and stored in a refrigerator at $-80^{\circ} \mathrm{C}$ until use.

The proteins from hemp seeds was also extracted using the protein extraction kit. Hemp seed powder was added to the RIPA (radio immunoprecipitation assay) lysis buffer $(50 \mathrm{mM}$ Tris $(\mathrm{pH}=7.4), 150 \mathrm{mM} \mathrm{NaCl}, 1 \%$ Nonidet P 40, 0.5\% sodium deoxycholate) in a ratio of $1: 5(w / v)$, the mixture was stayed at $4^{\circ} \mathrm{C}$ for $20 \mathrm{~min}$, followed by centrifugation at $13,000 \mathrm{~g}$ for $30 \mathrm{~min}$ at $4^{\circ} \mathrm{C}$, the supernatants was freeze-dried and stored in a refrigerator at $-80^{\circ} \mathrm{C}$ until use.

\section{Preparation of Albumin and Globulin From Hemp Seeds}

The isolation of $2 \mathrm{~S}$ albumin, 11S globulin, and 7S vicilin-like protein present in the hemp seeds was performed using the Osborne fractionation method with slight modification. The degreasing method used for the isolation was the same as that described before. Hemp seed powder was added to deionized water in a ratio of $1: 10(w / v)$, and the mixture was stirred for $1 \mathrm{~h}$ at $37^{\circ} \mathrm{C}$, followed by centrifugation at $8,000 \mathrm{~g}$ for $30 \mathrm{~min}$ at room temperature. The resultant supernatant was transferred to a clean tube, and the precipitate was added to deionized water in a ratio of $1: 5(w / v)$. The sample was stirred for $1 \mathrm{~h}$ at $37^{\circ} \mathrm{C}$ and centrifugated at $8,000 \mathrm{~g}$ for $20 \mathrm{~min}$. The supernatants from two centrifugations were combined and used for obtaining the water-soluble protein (Cs2S). In order to obtain the salt-soluble proteins, $1 \mathrm{M} \mathrm{NaCl}$ solution was added to the precipitate in a ratio of $1: 10(w / v)$, followed by stirring for $1 \mathrm{~h}$ at $30^{\circ} \mathrm{C}$ and then centrifugation at $8,000 \mathrm{~g}$ for $20 \mathrm{~min}$ at room temperature; the supernatant was transferred to a clean tube. The same operation was repeated using the changed $\mathrm{NaCl}$ ratio of $1: 5(w / v)$, and the two supernatants were combined to obtain the salt-soluble proteins (11S globulin and 7S vicilin-like protein). The flowchart of production of HSP using different methods is presented in Figure 1.

\section{Sodium Dodecyl Sulfate-Polyacrylamide Gel Electrophoresis (SDS-PAGE) Analysis}

The SDS-PAGE analysis was performed using 10\% separating gel and $2 \%$ stacking gel. The samples were diluted to an appropriate concentration $(1 \mathrm{mg} / \mathrm{mL})$ using the PBS buffer, followed by the addition of $5 \mathrm{X}$ protein loading buffer containing $\beta$-mercaptoethanol, heating at $95^{\circ} \mathrm{C}$ for $5 \mathrm{~min}$, and then cooling and centrifugation. Electrophoresis was performed at $80 \mathrm{~V}$ at room temperature in stacking gel, and afterward at $100 \mathrm{~V}$, using Bio-rad Mini protein (Bio-rad, Hercules, USA). The composition of running buffer was $192 \mathrm{mM}$ glycine, $25 \mathrm{mM}$ Tris, and $0.1 \%$ SDS. After the completion of electrophoresis, the gels were stained with $0.25 \%$ Coomassie brilliant blue, decolored using $7 \%$ acetic acid [methanol:acetic:water $=1: 1: 8(v / v / v)$ ], and then retained for analysis. Different boiling times and $2 \mathrm{ME}(\beta-$ mercaptoethanol) contents were used as they may effect degree of protein denaturation.

\section{Protein Identification Analysis}

The SDS-PAGE gel was soaked in $50 \mu \mathrm{L}$ of pure water for $30 \mathrm{~min}$ and then removed and cut into 1-2 $\mathrm{mm}$ gel pieces, decolored using the decolorizing solution $\left(50 \mathrm{mM} \mathrm{NH}_{4} \mathrm{HCO}_{3}\right.$ :acetonitrile $1: 1, v / v)$ and dehydrated using acetonitrile until the micelles were completely white. This was followed by adding $10 \mathrm{mM}$ DTT (dithiothreitol) to reduce the sulfhydryl groups, and then the micelles were dehydrated using $1 \mathrm{ug} / \mu \mathrm{L}$ trypsin and incubated overnight at $37^{\circ} \mathrm{C}$. The next day, 5 volumes of $50 \% \mathrm{MeCN}$ (acetonitrile) were added, and centrifugation was performed at $5,000 \mathrm{~g}$ for $1 \mathrm{~min}$. The resulting supernatant was centrifuged at $25,000 \mathrm{~g}$ for $5 \mathrm{~min}$, and the obtained supernatant was freeze-dried. 


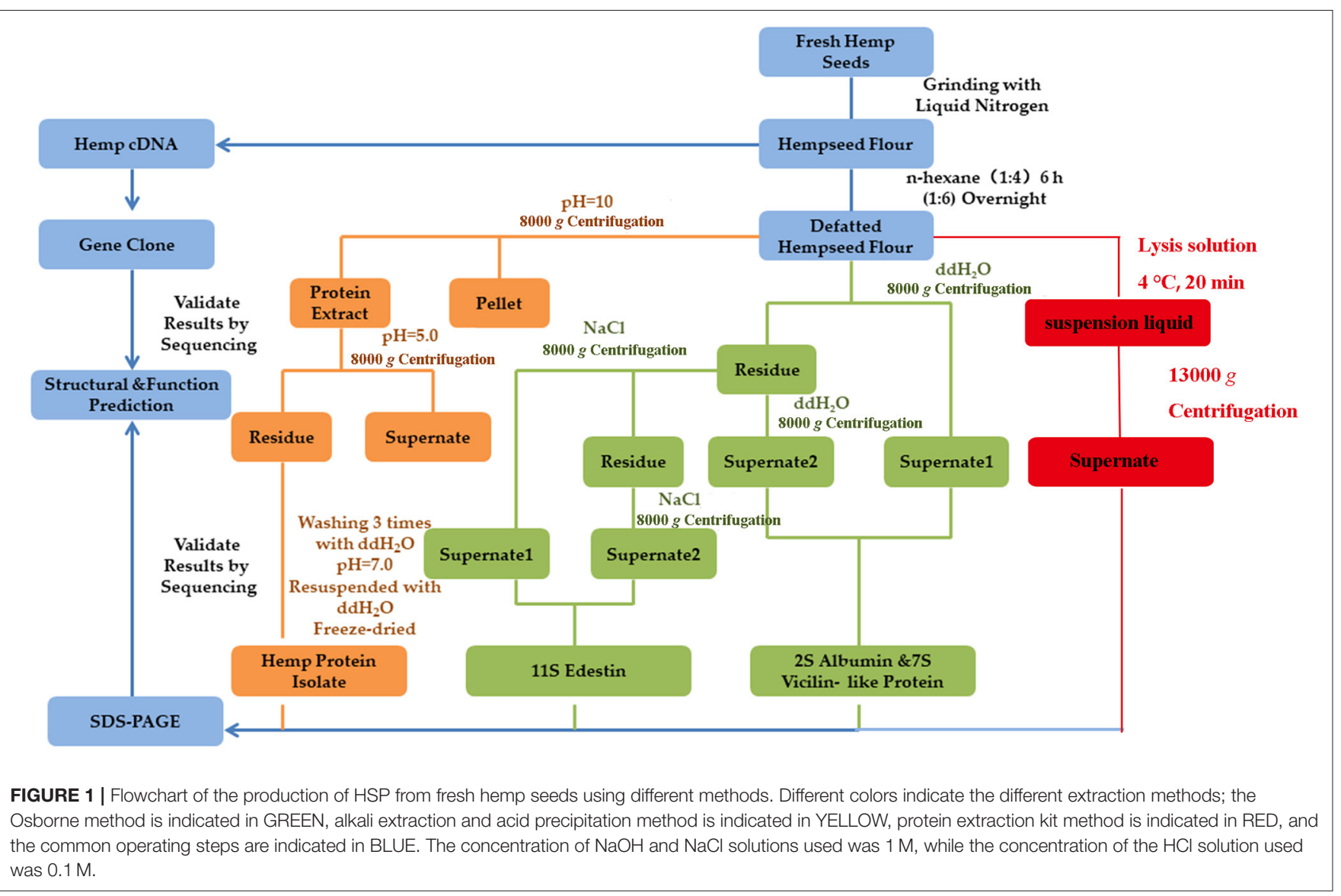

The dried peptide samples were reconstituted with mobile phase A [2\% ACN, 0.1\% FA (formic acid)], centrifuged at 20,000 $g$ for $10 \mathrm{~min}$, and the supernatant was taken for injection. Separation was carried out by a Shimadzu LC-20AD model nanoliter liquid chromatography system. The sample was first enriched in a trap column and desalted, and then entered a tandem self-packed C18 column (75 micron internal diameter, 3 micron column size, $20 \mathrm{~cm}$ column length) and separated at a flow rate of $300 \mathrm{~nL} / \mathrm{min}$ by the following effective gradient: 0-8 min, 5\% mobile phase B ( $98 \% \mathrm{ACN}, 0.1 \% \mathrm{FA}) ; 8-90 \mathrm{~min}$, mobile phase B linearly increased from 8 to $21 \%$; $90-102 \mathrm{~min}$, mobile phase $B$ rose from 21 to $32 \% ; 102-110 \mathrm{~min}$, mobile phase B increased from 32 to $80 \%$; $110-115 \mathrm{~min}, 80 \%$ mobile phase B; 115-120 min, 5\% mobile phase B. The nanoliter liquid phase separation end was directly connected to the mass spectrometer. The peptides separated using liquid-phase chromatography were ionized using a nanoESI source and then passed through a tandem mass spectrometer LTQ Orbitrap Velos (Thermo Fisher Scientific, San Jose, CA, USA) for DDA (data-dependent acquisition) mode detection. The main parameters were set: the ion source voltage was set to $2.2 \mathrm{kV}$; the MS1 scan range was $350-1,500 \mathrm{~m} / \mathrm{z}$; the resolution was set to 30,000 ; the MS2 starting $\mathrm{m} / \mathrm{z}$ was fixed at 100 ; the resolution was 7,500 . The screening conditions for the MS2 fragmentation were: charge $2+, 3+$ and $4+$ or higher, and the top 8 parent ions with the peak intensity exceeding 1,000. The ion fragmentation mode was HCD (higher energy C trap dissociation) with NCE (normalized collisional energy) set to 35 , and the fragment ions were detected in Orbitrap. The dynamic exclusion time was set to $15 \mathrm{~s}$.

Protein identification was achieved using experimental MS/MS data and aligning the data with the theoretical MS/MS data from a database to obtain the results. The databases used were the UniProt protein database and Cannabis sativa protein database in NCBI. The results from the search engine were preprocessed and re-scored using Percolator/[1/] to improve the matching accuracy. The output was then filtered at FDR $1 \%$ at the spectral level (PSM-level FDR $\leq 0.01$ ) to obtain a significant identified spectrum and peptide list. Subsequently, based on the parsimony principle, protein inference was performed on the peptides to generate a series of protein groups. The peptide, protein and spectrum list of all the samples can been seen in the Supplementary Table 2.

\section{Cloning of Hemp Seed Storage Protein Gene Family}

Fresh hemp seeds were ground with liquid nitrogen and subjected to total RNA isolation using the RNA extraction kit. The isolated total RNA was digested with RNase-free DNase I and then reverse-transcribed to be used as the template of PCR amplification. The RNA was detected using 2\% agarose gel 
electrophoresis. The primers for gene cloning, presented in Supplementary Table 1, were obtained from E. Ponzoni's report (38). The PCR amplification was conducted using the KOD enzyme. The amplification program was as follows: $94^{\circ} \mathrm{C}$ for $5 \mathrm{~min}, 30$ cycles of $15 \mathrm{~s}$ at $94^{\circ} \mathrm{C}, 30 \mathrm{~s}$ at $65^{\circ} \mathrm{C}$, and $2.5 \mathrm{~min}$ at $68^{\circ} \mathrm{C}$, and a final extension for $10 \mathrm{~min}$ at $68^{\circ} \mathrm{C}$. The specific bands amplified in PCR were purification and cloned in the pGEM-T plasmid. The positive clones were sequenced in both directions.

\section{Sequence Analysis}

All protein sequences obtained were compared with those of soybean proteins. Soybean proteins were selected because they are among the most important and commonly used plant sources of high-quality proteins. Sequences of soybean proteins were obtained from NCBI (https://www.ncbi.nlm.nih.gov/), accession numbers were P19594, P04347, and XP_003542001. Nucleotide sequences were analyzed using Condon code Aligner (https:// www.codoncode.com/aligner/download.htm) and BLAST search programs in NCBI (https://blast.ncbi.nlm.nih.gov/Blast.cgi) to examine the sequences and identify their homologous genes. Pairwise sequence alignment and multiple alignments were performed using EMBOSS Needle and Clustal Omega (http:// www.ebi.ac.uk/Tools). SignalP and NetNGlyc were employed to predict the putative $\mathrm{N}$-terminal signal sequences and $\mathrm{N}$ glycosylation sites, which were publicly available at (http:// www.cbs.dtu.dk/services/SignalP/) and (http://www.cbs.dtu.dk/ services/NetNGlyc/). The Phyre2, a website for predicting the secondary and tertiary protein structures, was used for predicting the structures of the concerned proteins (http://www.sbg.bio.ic. ac.uk/phyre2/html). Amino acid analysis and molecular mass estimation were performed using the ProtParam tool (https:// web.expasy.org/protparam/).

\section{RESULTS}

\section{SDS-PAGE Analysis}

The SDS-PAGE profiles of the proteins extracted using the different methods are presented in Figure 2. All proteins extracted using the different methods, except for the protein obtained using the kit method, contained three bands of sizes 47,35 , and $20 \mathrm{kDa}$. The proteins extracted using the kit had one band of size $47 \mathrm{kDa}$ and two bands of size $18 \mathrm{kDa}$. The water-soluble proteins presented four bands of size 46, 35, 18, and $14 \mathrm{kDa}$, while the salt-soluble proteins also had four bands of size $47,35,22$, and $18 \mathrm{kDa}$. The urea-soluble proteins exhibited the same pattern as that of the salt-soluble protein. As stated earlier, edestin has a hexamer structure composed of six identical subunits, each of which consists of an acidic subunit (AS) and a basic subunit (BS) linked via disulfide bonds. These disulfide bonds were broken during SDS-PAGE because of the presence of 2-ME, thereby generating the band of size $35 \mathrm{kDa}$ for AS and bands of size around $20 \mathrm{kDa}$ for $\mathrm{BS}$. The $47 \mathrm{kDa}$ band was for the $7 \mathrm{~S}$ vicilin-like protein, while the minor water-soluble protein was probably albumin, as suggested in previous research.

The Osborne fractionation method appeared to be the best method for the extraction of hemp seed storage proteins as this method could extract all 3 types of proteins without denaturing
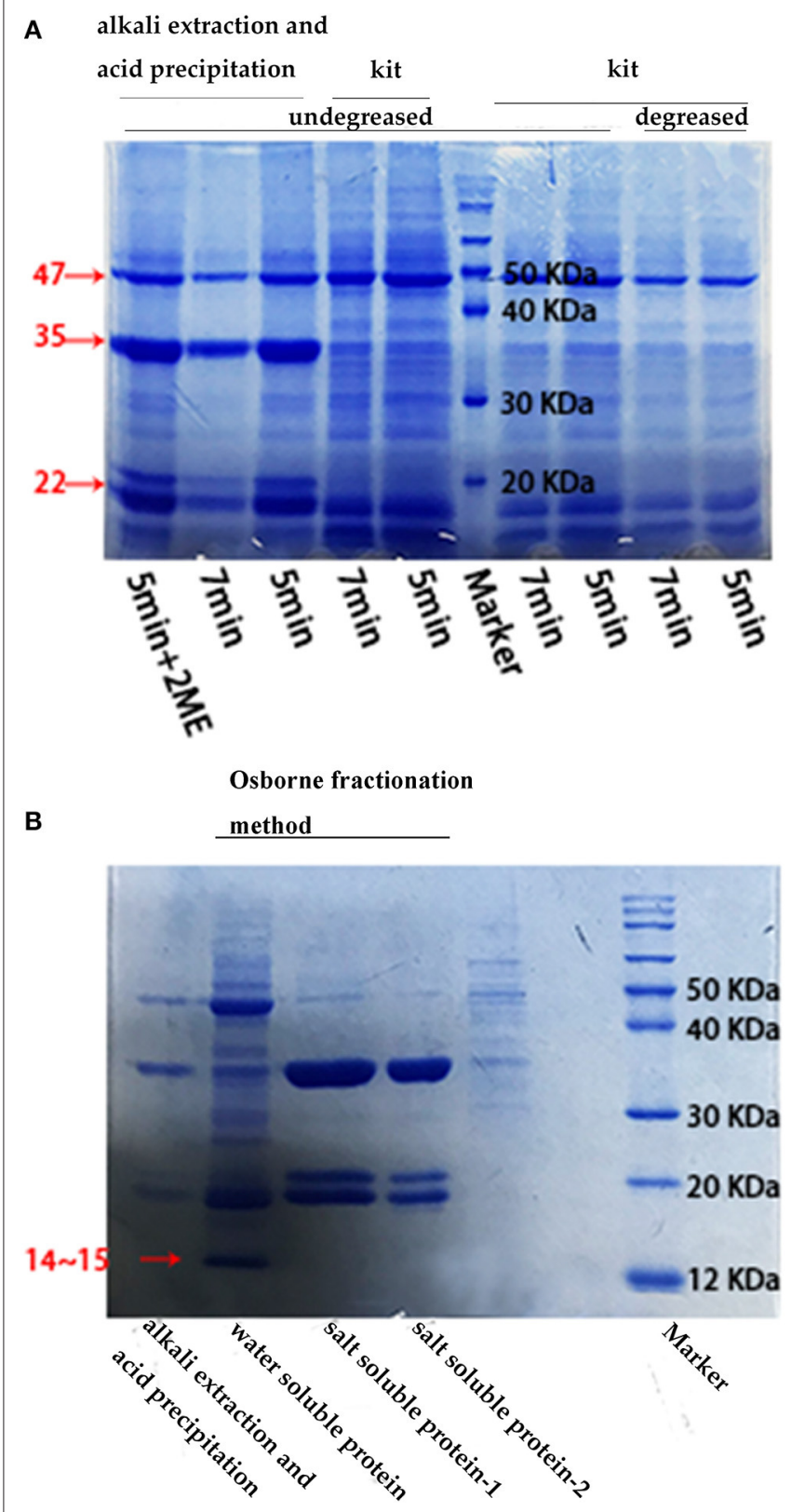

FIGURE 2 | SDS-PAGE results under different conditions. (A) SDS-PAGE electrophoresis of defatted/undefatted hempseed protein extracted using different methods. The time indicated the protein boiling time at $95^{\circ} \mathrm{C}$ and the $2 \mathrm{ME}$ concentration was 2.5\%; (B) SDS-PAGE electrophoresis of raw hempseed protein extracted using the "acid precipitation and alkaline extraction" method and the Osborne fractionation method (for water-soluble and salt-soluble proteins, respectively). The salt-soluble protein-1 was extracted using $\mathrm{NaCl}$, while the salt-soluble protein-2 was extracted using urea. The concentrations of $\mathrm{NaCl}$ was $1 \mathrm{M}$ and of urea was $8 \mathrm{M}$, the boiling time was $5 \mathrm{~min}$.

the protein structures as no strong acid and alkali were used in this method. The acid-precipitation-alkali extraction method could extract most hemp seed storage proteins, although $2 \mathrm{~S}$ albumin could not be obtained using this method; besides, the 
method may lead to protein denaturation because of the use of $\mathrm{NaOH}$. The performance of the commercial plant protein extraction kit in the extraction of HSP was not quite satisfactory as it could extract only a small portion of the hemp seed storage protein. The proteins detected in the electrophoretic profiles were in the same range of molecular weight as that reported previously for these proteins ( $2 \mathrm{~S}$ albumin: $<15 \mathrm{kDa}$, edestin: 30 and 20 $\mathrm{kDa}, 7 \mathrm{~S}$ vicilin-like protein: $47 \mathrm{kDa}$ ). In addition, degreasing, boiling time, and reducing agent content were observed to have little effect on hemp seed storage protein extraction and SDSPAGE results.

\section{Protein Identification Analysis}

The target bands of proteins were isolated using SDS-PAGE and then analyzed by LC-MS/MS. The databases used were UniProt protein database and Cannabis sativa protein database in NCBI. Using the search engine, results displayed that a total of 372 proteins and 1,521 peptides were identified from sample 40$50 \mathrm{kDa}, 369$ proteins and 1,333 peptides were identified from sample $35 \mathrm{kDa}, 265$ proteins and 773 peptides were identified from sample $20 \mathrm{kDa}-1,281$ proteins and 797 peptides were identified from sample $20 \mathrm{kDa}-2$, and 126 proteins and 305 peptides were identified from sample $<20 \mathrm{kDa}$ using the search engine (Table 1).

The basic statistical charts for protein identifications were depicted in Figure 3. The results were filtered based on the $\mathrm{Q}$ score of identified proteins, numbers of unique peptides, coverage, and molecular weight, proteins with significant differences in molecular weight compared to those reported previously were excluded (data provided in Supplementary Table 2). It could be inferred that the identified protein from sample $<20 \mathrm{kDa}$ was $\mathrm{Cs} 2 \mathrm{~S}$, that from samples $20 \mathrm{kDa}-1,20 \mathrm{kDa}-2$, and $35 \mathrm{kDa}$ was edestin, and that from sample $40-50 \mathrm{kDa}$ was Cs7S. It could be concluded from the identification results that the protein extracted was indeed the target protein. Three main types of seed storage proteins were present in this variety of hemp: Edestin, which was the most abundant seed storage protein and was composed of two subunits of molecular mass of 35 and $18-20 \mathrm{kDa}$, respectively; Cs2S, which had a molecular mass of $14 \mathrm{kDa}$; and Cs7S which was the least abundant and had a molecular mass of $\sim 47 \mathrm{kDa}$.

\section{Cloning of the Gene Family Encoding Hemp Seed Storage Proteins}

All target genes were amplified using PCR (Figure 4A). The genes encoding Edestin1, 2, and 3 were of 1,500 bp, the gene encoding Cs2S was of $400 \mathrm{bp}$, and the gene encoding Cs7S had $\sim 1,500 \mathrm{bp}$. After purification, the target fragments were cloned into the T-vector, and the selected positive clones were subjected to sequencing (Figures 4B,C). A BLAST search of all putative genes in the NCBI database revealed a high identity and similarity (98\%) with the hemp seed storage proteins (Supplementary Figure 1).

\section{Sequence Analysis of Hemp Seed Storage Protein Genes \\ 2S Albumin}

The coding sequence of Cs $2 S$ obtained from hemp seed was 423 bp in length, encoding 140 amino acid residues with two glycosylation sites. This sequence also contained an $\mathrm{N}$ terminal signal sequence comprising 23 residues for ER-targeting and a processing site for splitting into a small subunit and a large subunit.

The predicted molecular weight of Cs2S was $16.34 \mathrm{kDa}$, while the theoretical PI was 6.51 (determined using ExPASy compute $\mathrm{pI} / \mathrm{MV}$ tool). The total number of negatively charged residues (Asp + Glu) was 20, and positively charged residues (Arg + Lys) was 19. BLAST results confirmed that it was indeed hemp $2 \mathrm{~S}$ albumin. The secondary structure prediction data displayed that Cs2S had 70\% helix and 11\% TM helix content and no beta strands, indicating that the protein might have a transmembrane domain, which was in accordance with the SMART predicted results, Cs2S indeed had a transmembrane domain (7-24 amino acid residues) and a conservative AAI domain (48-135 amino acid residues). The AAI domain was represented by a structural domain consisting of 4 helices in a folded-leaf topology, forming a right-handed superhelix. Previous studies reported that this kind of domain occurred in several proteins, including the plant lipid transfer protein, seed storage proteins, and trypsin-alpha amylase inhibitor domain family of proteins.

The alignment of Cs2S and soybean $2 \mathrm{~S}$ albumin did not reveal a close association between these in the coding sequence. Cs2S was only $21.7 \%$ identical to the soybean $2 \mathrm{~S}$ albumin, although both proteins had typical characteristics of $2 S$ albumin, i.e., the N-terminal signal peptide targeting ER and 8 conserved cysteine residues linked via disulfide bonds (Figure 5A). The amino acid analysis revealed that soybean $2 \mathrm{~S}$ albumin contained 20 amino acids, while Cs $2 S$ contained one less, which was tryptophan. In addition, both $2 \mathrm{~S}$ albumins contained 9 essential amino acids required by human body. The most abundant amino acid in Cs2S was arginine, while that in soybean $2 \mathrm{~S}$ albumin was Glu. Moreover, Cs2S contained higher contents of Val, Tyr, Arg, and Ala compared to soybean $2 \mathrm{~S}$ albumin, while soybean $2 \mathrm{~S}$ albumin contained more Lys than Cs2S. The $\mathrm{E} / \mathrm{T}$ value of Cs2S was $34.3 \%$, lower than soybean $2 \mathrm{~S}$ albumin (41.1\%), however, its content of sulfur-containing amino acids was higher than that of soybean (Table 2). The Arg/Lys ratio of Cs2S (3.74) was significantly higher than that of soybean (0.6). The tertiary structure prediction results revealed that most similar structure to Cs2S was the Brazil nut $2 \mathrm{~S}$ albumin bere 1 (Supplementary Figure 2), which was composed of two large subunits and one small subunit connected via disulfide bonds.

\section{S Globulin}

Edestin1, Edestin2, and Edestin3 are all 11S globulins. Results of glycosylation site prediction and amino acid analysis revealed that all three edestins lacked a glycosylation site. Further, the number of amino acids in them was similar, where Edestin1 encoding 511 amino acids, Edestin2 encoding 491 amino acids, and Edestin 3 encoding 493 amino acids. 
TABLE 1 | Identification results overview.

\begin{tabular}{|c|c|c|c|c|}
\hline Sample & Total spectra & Identified spectra & Identified peptides & Identified proteins \\
\hline 40-50 kDa & 12,877 & 2,461 & 1,521 & 372 \\
\hline $35 \mathrm{kDa}$ & 12,483 & 2,992 & 1,333 & 369 \\
\hline $20 \mathrm{kDa}-1$ & 12,524 & 2,842 & 773 & 265 \\
\hline 20 kDa-2 & 11,835 & 3,119 & 797 & 281 \\
\hline$<20 \mathrm{kDa}$ & 10,306 & 2,228 & 305 & 126 \\
\hline
\end{tabular}

The DNA coding sequence alignment of the three edestins (using Clustal omega for amino acid sequence alignment) revealed significant differences between them. The similarity between Edestin 1 and Edestin 2 was only $57.8 \%$, between Edestin 2 and Edestin 3 was 58\%, between Edestin 1 and Edestin 3 was $62.7 \%$. The results of the alignment of amino acid sequences were similar to those obtained for the alignment of cDNA sequences. The identity and similarity of Edestin 1 with Edestin 3 were higher than those with Edestin2, with 57.5 and $73.5 \%$ (Table 3).

The predicted molecular weight of Edestin1 was 58.56 $\mathrm{kDa}$ and the theoretical PI was 8.44. The total number of negatively charged residues in Edestin 1 was 66 and that of positively charged residues was 69 . The corresponding values for Edestin2 were $55.98 \mathrm{kDa}, 9.02,57$, and 63, and for Edestin3 were $56.26 \mathrm{kDa}, 7.63,59$, and 60 (Table 4). The secondary structure prediction results demonstrated that the three edestins had similar secondary structures, containing a transmembrane helix with $\sim 30 \%$ beta strands and $20 \%$ alpha helix. Eedestin1 contained 20\% alpha helix, 28\% beta strands, and 3\% TM helix. Edestin2 had 19\% alpha helix, 31\% beta strands, and 3\% TM helix. Edestin3 had 18\% alpha helix, 29\% beta strands, and $3 \%$ TM helix. In the tertiary structure prediction, the most similar structure to these three edestins was that of the Wrightia tinctoria reveals auxin binding site $11 \mathrm{~S}$ globulin (Supplementary Figure 2).

The amino acid sequences of the three edestins were compared with those of soybean $11 \mathrm{~S}$ globulin (GL5) (Figure 5B). All edestins had common features of $11 \mathrm{~S}$ globulin, although there were a few differences among them. They also had an Nterminal signal peptide targeting ER, a cleavage site capable of splitting into two subunits (acidic subunit and basic subunit), four conservative cysteine residues, and two conservative Cupin structure domains. The Cupin family represented the conserved barrel domain of the "cupin" superfamily ("cupa" is the Latin term for a small barrel) and contained the $11 \mathrm{~S}$ and $7 \mathrm{~S}$ plant seed storage proteins and germins.

According to the amino acid composition analysis, 11S globulin, whether from hemp or soybean, contained 9 essential amino acids required by human body. The amino acid compositions of the three edestins were almost similar to each other, with Arg as the most abundant amino acid, while the most abundant amino acid in GL5 was Gln. Ala, Met, and Arg contents in the edestins were significantly higher than those in GL5, while GL5 had higher Pro content than that in the edestins. The content of Met was significantly lower in Edestin2 than that in the other two edestins and accounted for only $30 \%$ of the content in each of the other two edestins, while Edestin3 had more Cys and Met than those in the other two edestins. The E/T values and content of sulfur-containing amino acids of Edestin2 (34.2\%) and Edestin3 (35.1\%) were higher than those of GL5 (33.7\%), while Edestin1 (32.7\%) had a similar E/T value and content of sulfurcontaining amino acids compared with GL5. The Arg/Lys of all the three edestins were 5.27, 5.32 and 4.00, which were higher than that of GL5 (1.74) (Table 5).

In addition to the differences in amino acid composition, the proteins coded by these three edestin genes were different in molecular mass and subunits. The predicted molecular weight of Edestin1 was $58.56 \mathrm{kDa}$, that of its a-subunit was $34.35 \mathrm{kDa}$, and that of its b-subunit was $21.77 \mathrm{kDa}$, while the corresponding values for Edestin2 were 55.98, 32.58, and $20.84 \mathrm{kDa}$, and for Edestin 3 were $56.26,32.68$, and $21.17 \mathrm{kDa}$. It could be observed that the molecular weight of the protein unit encoded by the different edestin genes was $\sim 55-59 \mathrm{kDa}$ in size, with the size of its a-subunit $\sim 32-35 \mathrm{kDa}$ and size of its b-subunit $\sim 20-22$ $\mathrm{kDa}$. The molecular weight of the protein encoded by Edestin 1 gene was higher than those encoded by the other two genes, with Edestin2 gene encoding the smallest edestin (Table 4). The molecular weight of the protein containing the $\mathrm{N}$-terminal signal peptide and a-subunit sequence was calculated from the cleavage site of signal peptide to the cleavage site of acid-base subunit, while that for the b-subunit sequence was calculated from the cleavage site of acid-base subunit to the end of protein.

\section{S Vicilin-Like Protein}

The cDNA sequence of Cs7S was 1,479 bp in length, encoding 492 amino acids, its predicted molecular weight was $55.7 \mathrm{kDa}$ and the theoretical PI was 7.63. The BLAST results from NCBI also confirmed that the protein encoded by the gene was hemp $7 \mathrm{~S}$ vicilin-like protein. The secondary structure prediction results revealed that the protein encoded by Cs7S had 29\% beta strands, $20 \%$ helix, and 3\% TM helix. Similarly, as a secretory protein, Cs7S had one N-terminal signal peptide, one transmembrane region (7-25 amino acid residues), two coiled-coil regions (2657 and 258-285 amino acid residues), and two Cupin conserved domains (58-212 and 311-460 amino acid residues), which were the typical domains of seed $7 \mathrm{~S}$ and $11 \mathrm{~S}$ storage proteins. The amino acid sequence alignment of Cs7S and Gly7S (7S vicilin protein from soybean) was conducted using EMBOSS Needle, which revealed the identity and similarity of 55.3 and $70.4 \%$, respectively, between Cs7S and Gly7S (Figure 5).

Different from the $11 \mathrm{~S}$ globulin and $2 \mathrm{~S}$ albumin proteins from hemp seed, the $7 \mathrm{~S}$ vicilin-like protein contained only 
A

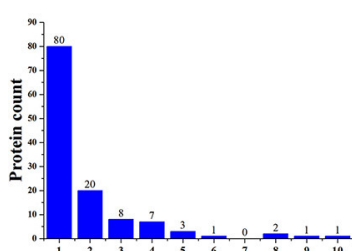

(s) $126 \quad$ Unique peptide number

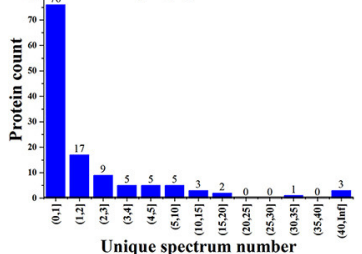

$<20 \mathrm{kDa}$

C
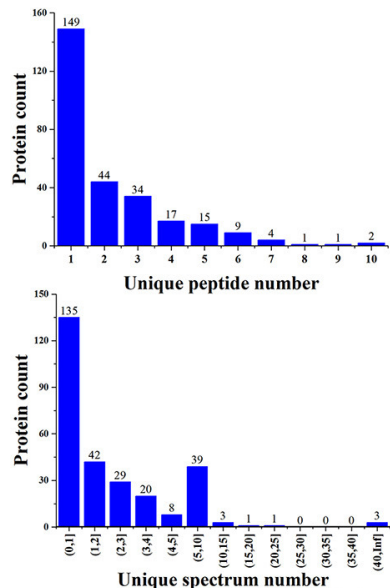

20 kDa-2

E
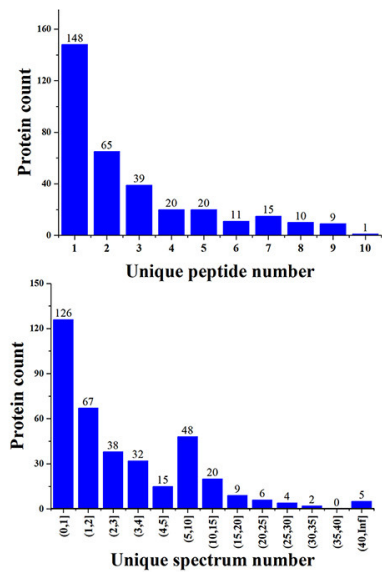

40-50 kDa
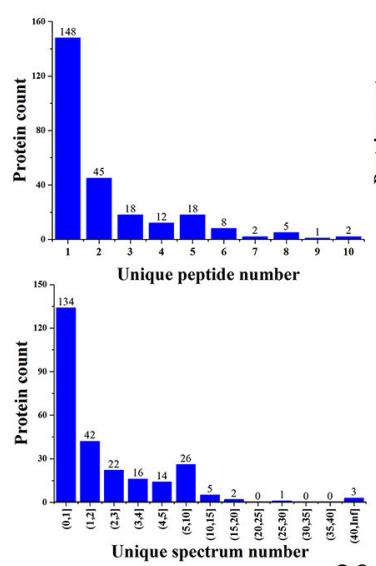

20 kDa-1

D

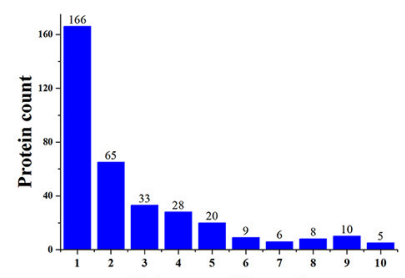

Unique peptide number
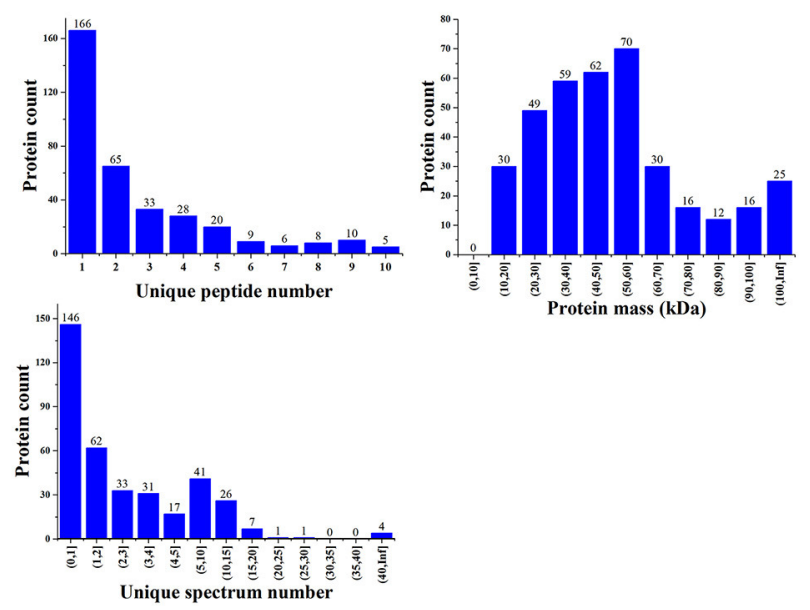

$35 \mathrm{kDa}$

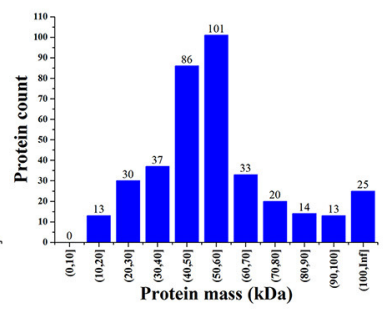

FIGURE 3 | Basic statistical charts for the protein identifications. (A) Identification results for proteins in the 40-50 kDa range. (B) Identification results for proteins in the $30-40 \mathrm{kDa}$ range. (C,D) Identification results for proteins in the $20 \mathrm{kDa}$ range. (E) Identification results for proteins in the $<20 \mathrm{kDa}$ range.

one conserved cysteine residue, although it had four NXT glycosylation sites. The amino acid composition analysis revealed that Leu was the most abundant amino acid in the Cs7S protein, while Glu was the most abundant amino acid in Gly7S. The His content in Cs7S was significantly lower than that in the soybean protein. The E/T values of Cs7S (43.5\%) and Gly7S (44.5\%) were 
A

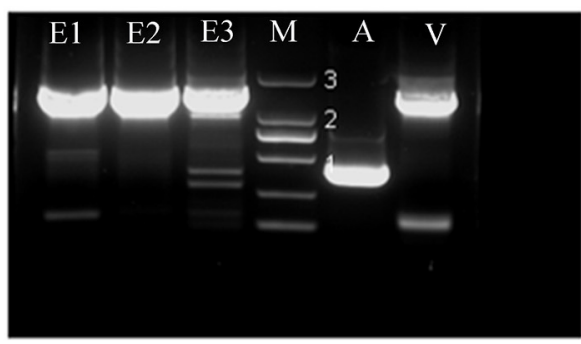

B

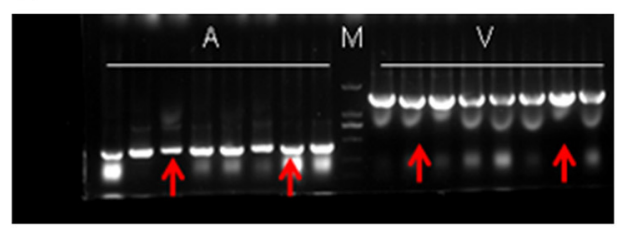

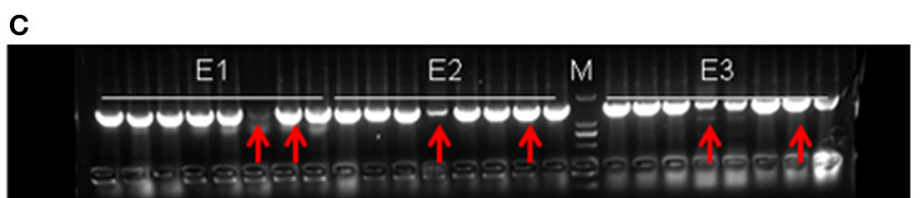

FIGURE 4 | The electropherogram of gene cloning. (A) Result of PCR amplification. (B,C) PCR results for the recombinant vectors; the red arrows indicate the positive clones sent for sequencing. E1: edestin1; E2: edestin2; E3: edestin3; A: 2S albumin; V: 7S vicilin-like protein. Numbers 1, 2, and 3 indicate DNA marker bands, representing 500, 1,000, and 2,000 bp, respectively.

similar, however, Gly7S had more sulfur-containing amino acids (Table 2). The tertiary structure prediction results revealed that the protein with the most similar structure to Cs7S was vicilin from Solanum melongena (Supplementary Figure 2).

\section{DISCUSSION}

In the present research, hemp seed storage proteins were extracted using different methods, and the results were compared. The Osborne fractionation method used in the present study could result in different hemp seed storage proteins with solubility differences and would not lead to protein denaturation because of its mild extraction conditions, which was conducive to the subsequent experiments. The acid precipitation and alkali extraction method was the most common method for extracting HSP (39). Protein denaturation is inevitable when using these methods owing to the addition of a strong alkali during the extraction process, which may affect the results of the subsequent experiments. Therefore, the modified Osborne fractionation method might be a better extraction method for use in HSP research. Moreover, it was observed that degreasing had little effect on protein extraction results. The extracted proteins were qualitative analyzed and protein sequence alignment analyzed using LC-MS/MS and BLAST, respectively, which finally confirmed that the extracted proteins were indeed hemp seed storage proteins. In Longma 5, the main seed storage proteins were $11 \mathrm{~S}$ globulin, $2 \mathrm{~S}$ albumin, and $7 \mathrm{~S}$ vicilin-like protein, among which $11 \mathrm{~S}$ globulin was the most abundant, followed by $2 \mathrm{~S}$ albumin and $7 \mathrm{~S}$ vicilin-like protein.

Gene families encoding hemp seed storage proteins were cloned, followed by the analysis of the coding sequences and amino acid composition and the prediction of the secondary and tertiary structures of proteins. One $2 \mathrm{~S}$ albumin gene was cloned in this research, the cDNA length of Cs $2 S$ was $423 \mathrm{bp}$, encoding
140 amino acids. The predicted molecular weight of Cs2S was $16.34 \mathrm{kDa}$, amino acid sequence analysis showed, in agreement with previous studies, that Cs2S had the typical structure of $2 \mathrm{~S}$ albumin, an ER-binding signal sequence containing 23 amino acid residues at the $\mathrm{N}$-terminal, eight conserved cysteine residues that form two intrachain disulfide bonds in the large subunit and two interchain disulfide bond linking subunits in the mature protein, and a cleavage site that divides the protein into two subunits $(38,40)$. The most abundant amino acid of Cs2S was Arg (10.7\%), in comparison with soybean $2 \mathrm{~S}$ albumin, Cs2S contained higher Val, Tyr, Arg, and Ala amino acid contents. Although the $\mathrm{E} / \mathrm{T}$ value of Cs2S was lower than that of soybean $2 \mathrm{~S}$ albumin, however, it has a higher content of sulfur-containing amino acids. This sulfur-rich proteins have no inhibitory activity against trypsin and could serve as a rich thiol source to formulate highly nutritious foods, since various plant food proteins, especially legumin proteins from soybean, pea, and beans, are deficient in sulfur. These results were consistent with those reported by Ponzoni et al. (38), which reported that $18 \%$ wt (weight) of Cs $2 S$ was due to the sulfur-containing amino acids, while they were different from the findings reported by McKernan et al. (41), with the latter reporting that albumin encoded 151 amino acids and contained higher Tyr and Pro and less Glu compared to the values obtained in the present work. The E/T value of Cs2S in the present work was higher than that in McKernan's research, which indicated that Longma 5 had a better amino acid composition.

The analyses identified three edestin genes, namely Edestin1,2 and 3. The predicted molecular weight of protein encoded by Edestin1 was higher than that of proteins encoded by the other two genes, with Edestin2 being the smallest. Edestin is a hexameric structure comprising six identical subunits, each of which consisted of an acidic subunit (AS) and a basic subunit (BS) linked by disulfide bonds. The molecular weight of AS was $\sim 35 \mathrm{kDa}$ and BS contained two subunits of $\sim 20 \mathrm{kDa}$. The result was consisted with previous research from Svedberg and Stamm, 
A

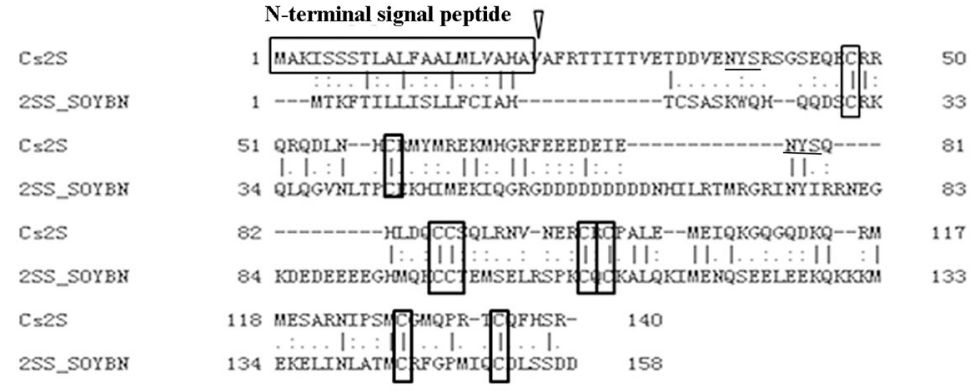

B

CLUSTaL O(1.2.4) multiple sequence alignment

CLUSTAL $0(1.2 .4)=$ tultipl
sp| P04347| GLYGS_SOYBN
edestin-2
edestin-1
edestin-3

$\mathrm{N}$-terminal signal peptide

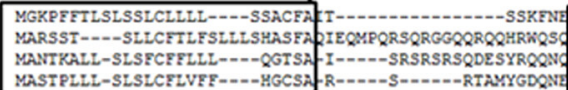

LNRLNILLEPDHRVESEGGLIETWNS---QHPEL IF GVTVSKRTLNRNGSHLPSYLPYPQMITVVQ 97 FQRLNIARQPNRRVECEAGVSEYWDIQNTEDDEL: FN GVETARHTIQRRGLLLPSFLNAPNATFYIQ 116

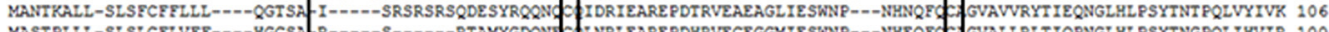

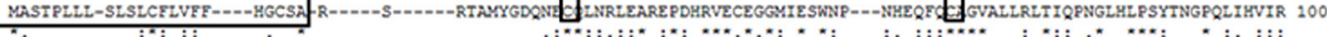

ID|P04347|GLYGS_SOYBS edestin-2 edestin-1 edestin-3

sp | P04347। GLYGS_SOYBN edestin-2
edestin-1 edestin-3

SD| P04347 | GLYGS_SOYBN edestin-2 edestin-3

SD|P04347|GLYGS_SOYBN edestin-2

edestin-1

GKGAIGFAFPG F ETFERPQQQSSRRGSR-SQQQLQDSHQRIRHFEEGDVLVIPLGVPYWTYNTGDEPVVAISPLDTSNFNNQLDQNPRVFYLAGNPDIEHPETMQQQQQQRSHGGRKQG 216 GRGIHGAVIPC F ETFERGTSSPPSRGYREGASSDEQHQKVREIKEGDMVMMPAVVDWVMNGDSPLVLIAFVDVGNQANQLDQFSRRFHLAGNPHREQKTQQQVRARSQS-----RS 231 GRGILGVTFPC ETFEESQRGQ---GQGQSQGSQPDRRQKLRHVREGDIVAIPAGVAYWSYNGDQQLVFVSLLDTSNVNNQLDDNPRRFYLAGMPEDEFEQLRREGGRGARFDERIRE 223

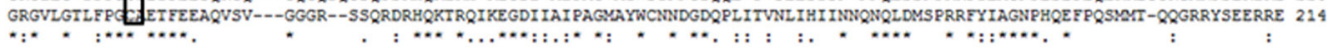

Q---HRQQEEEGSVLSGFSKHFLAQSFITIEDTAEKLRSPDDERKQIVTVEGG-LSVISPKWQEQEDEDEDEDEEYGRTPSYPPRRPSHGKHEDDEDEDEEEDQPRPDMPPQRPSRPEQ 332 QLRRESGEQTPNGNI FSGFDTRI LAESFNVTELAHKLQNRDDMRERIVRVRGEDLQI IAPSRIQEEE-

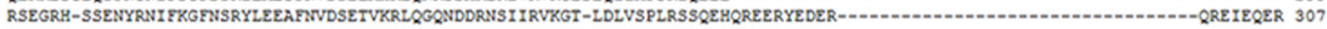

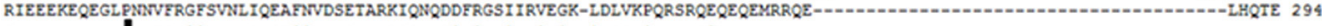

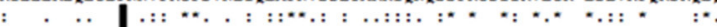

QEPRGRGCQTRUGVEEN CWRLHENIARPSRADFYNPKAGRISTLNSLTLPALRQFGLSAQYVVLYRNGTYSPDWNLNANSVT-MTRGKGRVRVVNCQGNAVFDGELRRGQLLVVPQNP 45,

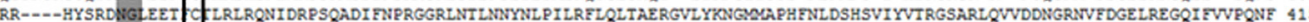

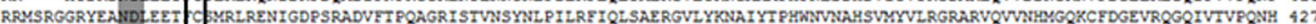

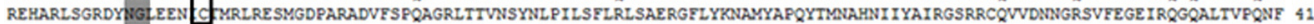
$\therefore$.

AVAEQGGEQGLEYVTKTHMNAVSYIK---DVFRVI PSEVLSNSYHLQSQVRQLKYQGNSGPLVIP---------------- 516

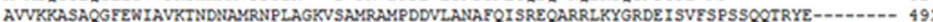
AVVRQASSDGFEWVSFKTNDNAWVSPIAGRTSVIRALPEAVL ANAFQISRDQARNLKYNREETVUTSSTSSRREDRYERRATA S1 AVWROEKEGFEWVSFKTNDRAQVNQLAGKISTMRAYPEDVIANSYQISREQARRLKYNREESSLFTISHQGIRAVIA----- 493

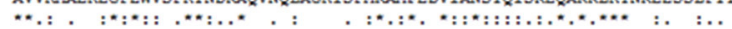

C

\begin{tabular}{|c|c|c|c|c|}
\hline \multirow{3}{*}{ Cs7S-like } & \multicolumn{2}{|r|}{ N-terminal signal peptide } & \\
\hline & 1 & MGRIKLTLLVLMLVLSYGVLGI & GGDEDEDWTREKERKKEEEREKEREREDERGELPFILRDSKHVMRTDAGEMRVMRSSDSKFAQGPLRIGFITMEPKT & 100 \\
\hline & & फ.:::!ा: & 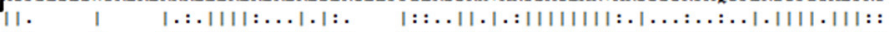 & \\
\hline XP_003542001. & 1 & MGS-RMSLLMLFLVLCHGVALTR & MGL-----W-----RTEVEEREEGHPRPDKL----FMLKSKRVAQTDAGEMRVLESYGGRILERRLNIGFIMMEPRS & 85 \\
\hline Cs7s-1ike & 101 & LFLPQYLDSELTIFIRRGEVKLC & GFIYKDQLAERKLKTGDVYRISAGSAFYLVNTGEGQRLHIICSFDTSESLRIGTFQSFFLGGGTNPASILSGFDSEIL & 200 \\
\hline & & $\|:||||:|| \cdot|\cdot||:| \cdot|| \cdot|1|$ & 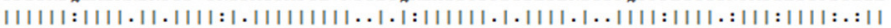 & \\
\hline XP_003542001. & 86 & LFIPQYIDSTLIIFLRSGEAKLC & GFIYKDKLAERHLKYGDVYQIPAGSAFYLVNIEEAQKLHIICSIDPSESLGIDIFQSFYLGGGAHPASVLSGFEPQIL & 185 \\
\hline Cs7s-like & 201 & ENAFNVTHAELKEILSIQQEGPI & IVYIPDSRSPKTWAKFLQLKQEDKLQHLKKIVGFHQGEEEDEEELEEDINQEQNQKTTWSWRKLLDSLFANRGKKTKD & 300 \\
\hline & & 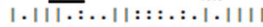 & 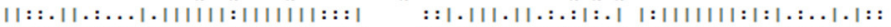 & \\
\hline XP_003542001. & 186 & ETAFNASGEELRKMFTRQHEGP & IVHVGDSHATSIWTKFLQLKEEDKL QHLREMV-----QQEQEEEEEEFVEEERQ-TSWSWRKLLESVFGDEIKNTRE & 279 \\
\hline Cs7S-like & 301 & YKGKGKSPDSYNLYDGKKGFKN: & NYYGSIALDEFSYSPLRKSGCGVYLVNLTAGSMMAPHLNPEATEYGIILKGTGMIQVVYPNGTSAMNTEVKEGDVFWV & 400 \\
\hline & & $|\ldots||| \cdot|\cdot||||\cdot| \ldots|| \mid$ & 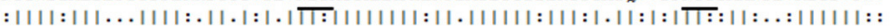 & \\
\hline XP_003542001. & 280 & -KVTKKSPHSCNLYDRKPDEKN & ISYGWSVALDGSEYSPLKSSGVGIYHVNLSAGSMMAPHVNPRATEYGIVLKGSGRIQIVFPNGSNAMDAHIKEGDVFFI & 378 \\
\hline Cs7S-1ike & 401 & PRYFPFCQIASRAGPMEFFGFT: & TSARKNRPQFLVGASSILRSMRGPELAAAFGLSLERLGNLTSYQRESVILPTSAASPPVKLAKPIRSLKE---1---- & 492 \\
\hline & & $1111.11 \| 1111 . .1: 111111$ & 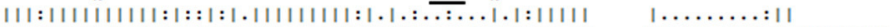 & \\
\hline XP_003542001. & 379 & PRYFAFCQIASRGEPLEFFGET & TSAQKNRPQFLVGATSLMTMVGPELAAAEGVSEETMNRVARAQHEAVILPT------PWAAHAHDHKVKEEVVVDIFQ & 473 \\
\hline Cs7s-like & 493 & ---------- & & \\
\hline XP_003542001. & 474 & KLARNE IMGE & & \\
\hline
\end{tabular}

FIGURE 5 | Alignment results of the coding sequences. (A) Alignment result for Cs2S and soybean 2S albumin. (B) Alignment results for the three Edestins and soybean $11 \mathrm{~S}$ globulin. Broken lines were introduced to maximize similarity. Asterisks indicate identical amino acids. (C) Alignment result of Cs7S and soybean 7S vicilin-like protein (XP_003542001). The cleavage site of signal peptide is indicated by open triangle, while the conserved cysteine residues are boxed. The black arrows indicate cleavage site for splitting these polypeptides into an acidic subunit and a basic subunit. The underlines indicate the predicted glycosylation sites.

which reported that AS was $34.0 \mathrm{kDa}$, while BS were 20.0 and $18.0 \mathrm{kDa}(32)$. All three edestins had a typical structure of $11 \mathrm{~S}$ globulin,which was consist with Ponzoni's research that all the edestins had an ER-binding signal peptide sequence containing 23 amino acid residues at the $\mathrm{N}$-terminal and four conserved cysteine residues (38). The identity and similarity of the coding 
TABLE 2 | Amino acid composition of 2S albumin and 7S vicilin protein.

\begin{tabular}{|c|c|c|c|c|c|c|c|c|}
\hline \multirow[t]{2}{*}{ Amino acid } & Number & Proportion (\%) & Number & Proportion (\%) & Number & Proportion (\%) & Number & Proportion (\%) \\
\hline & \multicolumn{2}{|c|}{ Cs2S } & \multicolumn{2}{|c|}{ Soybean 2S } & \multicolumn{2}{|c|}{ Cs7S } & \multicolumn{2}{|c|}{ Soybean 7S } \\
\hline Ala(A) & 9 & 6.428571 & 4 & 2.531646 & 25 & 5.081301 & 34 & 7.039337 \\
\hline Cys $(C)^{\#}$ & 8 & 5.714286 & 10 & 6.329114 & 3 & 0.609756 & 4 & 0.828157 \\
\hline Asp(D) & 6 & 4.285714 & 15 & 9.493671 & 22 & 4.471545 & 17 & 3.519669 \\
\hline Glu(E) & 14 & 10 & 17 & 10.75949 & 45 & 9.146341 & 47 & 9.730849 \\
\hline Phe $(F)^{\star}$ & 4 & 2.857143 & 3 & 1.898734 & 27 & 5.487805 & 28 & 5.797101 \\
\hline Gly(G) & 5 & 3.571429 & 7 & 4.43038 & 42 & 8.536585 & 37 & 7.660455 \\
\hline $\mathrm{His}(\mathrm{H})^{\star}$ & 5 & 3.571429 & 5 & 3.164557 & 6 & 1.219512 & 17 & 3.519669 \\
\hline$\| \mathrm{e}(\mathrm{l})^{\star}$ & 5 & 3.571429 & 11 & 6.962025 & 28 & 5.691057 & 29 & 6.004141 \\
\hline Lys $(K)^{\star}$ & 4 & 2.857143 & 15 & 9.493671 & 38 & 7.723577 & 27 & 5.590062 \\
\hline Leu(L)* & 8 & 5.714286 & 13 & 8.227848 & 50 & 10.1626 & 42 & 8.695652 \\
\hline $\operatorname{Met}(M)^{\star \#}$ & 10 & 7.142857 & 9 & 5.696203 & 13 & 2.642276 & 18 & 3.726708 \\
\hline Asn(N) & 6 & 4.285714 & 6 & 3.797468 & 16 & 3.252033 & 14 & 2.898551 \\
\hline Pro(P) & 3 & 2.142857 & 3 & 1.898734 & 22 & 4.471545 & 21 & 4.347826 \\
\hline $\mathrm{Gln}(\mathrm{Q})$ & 12 & 8.571429 & 12 & 7.594937 & 18 & 3.658537 & 19 & 3.933747 \\
\hline $\operatorname{Arg}(\mathrm{R})$ & 15 & 10.71429 & 9 & 5.696203 & 30 & 6.097561 & 27 & 5.590062 \\
\hline Ser(S) & 11 & 7.857143 & 9 & 5.696203 & 39 & 7.926829 & 36 & 7.453416 \\
\hline $\operatorname{Thr}(T)^{*}$ & 7 & 5 & 7 & 4.43038 & 25 & 5.081301 & 18 & 3.726708 \\
\hline $\operatorname{Val}(\mathrm{V})^{*}$ & 5 & 3.571429 & 1 & 0.632911 & 21 & 4.268293 & 30 & 6.21118 \\
\hline $\operatorname{Trp}(\mathrm{W})^{\star}$ & 0 & 0 & 1 & 0.632911 & 6 & 1.219512 & 6 & 1.242236 \\
\hline $\operatorname{Tyr}(Y)$ & 3 & 2.142857 & 1 & 0.632911 & 16 & 3.252033 & 12 & 2.484472 \\
\hline
\end{tabular}

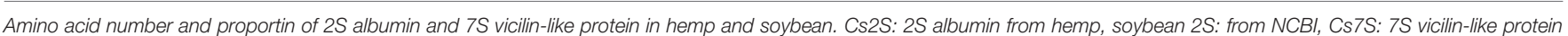
from hemp, soybean 7S: GLy from NCBI. Bold indicated the most abundant amino acid. *Indicated the essential amino acids. ${ }^{\#}$ Indicated the sulfur-containing amino acids.

TABLE 3 | Percentage of sequence similarity of coding sequences (CDS), amino acid sequences of edestins.

\begin{tabular}{lcccc}
\hline Sequence pairs & \multicolumn{2}{c}{ Coding sequence } & \multicolumn{2}{c}{ Amino acid sequence } \\
\cline { 2 - 5 } & Identity (\%) & Similarity(\%) & Identity (\%) & Similarity(\%) \\
\hline Edestin1/Edestin2 & 57.8 & 57.8 & 47.2 & 64.1 \\
Edestin1/Edestin3 & 62.7 & 62.7 & 57.5 & 73.5 \\
Edestin2/Edestin3 & 58.0 & 58.0 & 47.6 & 64.3 \\
\hline
\end{tabular}

sequence of Edestin1 with that of Edestin 3 were higher than those with Edestin2. Arginine was the most abundant amino acid in all the three edestins. Arginine accounts for $\sim 11 \%$ of edestins when compared with $<7 \%$ for most other food proteins, including the proteins from potato, wheat, maize, rice, soy (1). Arginine can enhance blood flow and contribute to the maintenance of normal blood pressure (42). Lysine and tryptophan are the main limiting amino acids in hempseed (5). The Arg/Lys ratio is a determinant of the cholesterolemic and antherogenic effects of a protein (43). The Arg/Lys ratio of edestins obtained in the present research were $5.27,5.32$ and 4.00 , which were remarkably higher than that of soybean (1.41) or casein (0.46), suggesting strong potential for edestins utilization in the formulation of cardiovascular healthpromoting food products. Hence, edestins can be considered as a nutritional and bioactive ingredient for the formulation of foods that promote cardiovascular health. It is noteworthy that the Met content of Edestin3 was significantly higher than that of the other two edestins, and it is well-recognized the Met content is related to the nutritional value of crops. Therefore, it could be inferred that Edestin 3 had a better nutritional value than the other edestins.

There was one Cs7S cloned in the present work. The coding sequence of the Cs7S was 1,479 bp and encoded 492 amino acids, it had four $\mathrm{N}(\mathrm{X}) \mathrm{T} \mathrm{N}$-glycosylation sites (X represents any amino acid except proline), two conserved Cupin domains, and an N-terminal signal peptide, which are present in most of the secreted proteins. The result obtained for Cs7S was consistent with those reported by Ponzoni and Docimo, although the amino acid sequences reported were not exactly the same $(38,44)$. The most abundant amino acid of Cs7S was Leu (10.16\%), the $\mathrm{E} / \mathrm{T}$ value of it was 43.49 , which was higher than albumin and edestins. However, comparing with albumin and edestins, Cs7S had a lower content of sulfur-containing amino acids and a lower Arg/Lys ratio. It can be seen that Cs7S has a good amino acid composition but is otherwise inferior to albumin and edestins.

Results obtained for Cs7S were slightly different from those reported by McKernan, who reported that potential Cs7S encoded 791 amino acids and contained higher Glu content than 
TABLE 4 | Sequence length, protein mass, and submit mass of three edestins.

\begin{tabular}{|c|c|c|c|c|c|}
\hline Edestin type & Coding sequence length (bp) & Amino acid residues & Protein mass (kDa) & A-subunit mass (kDa) & B-subunit mass (kDa) \\
\hline Edestin-1 & 1,536 & 511 & 58.56 & 34.35 & 21.77 \\
\hline Edestin-2 & 1,476 & 491 & 55.98 & 32.58 & 20.84 \\
\hline Edestin-3 & 1,482 & 493 & 56.26 & 32.68 & 21.17 \\
\hline
\end{tabular}

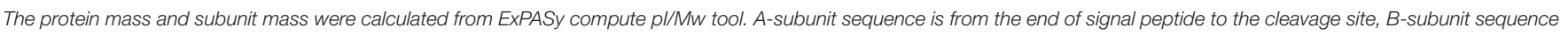
is from the cleavage site to the end of protein amino acid sequence.

TABLE 5 | Amino acid composition of 11 S globulins.

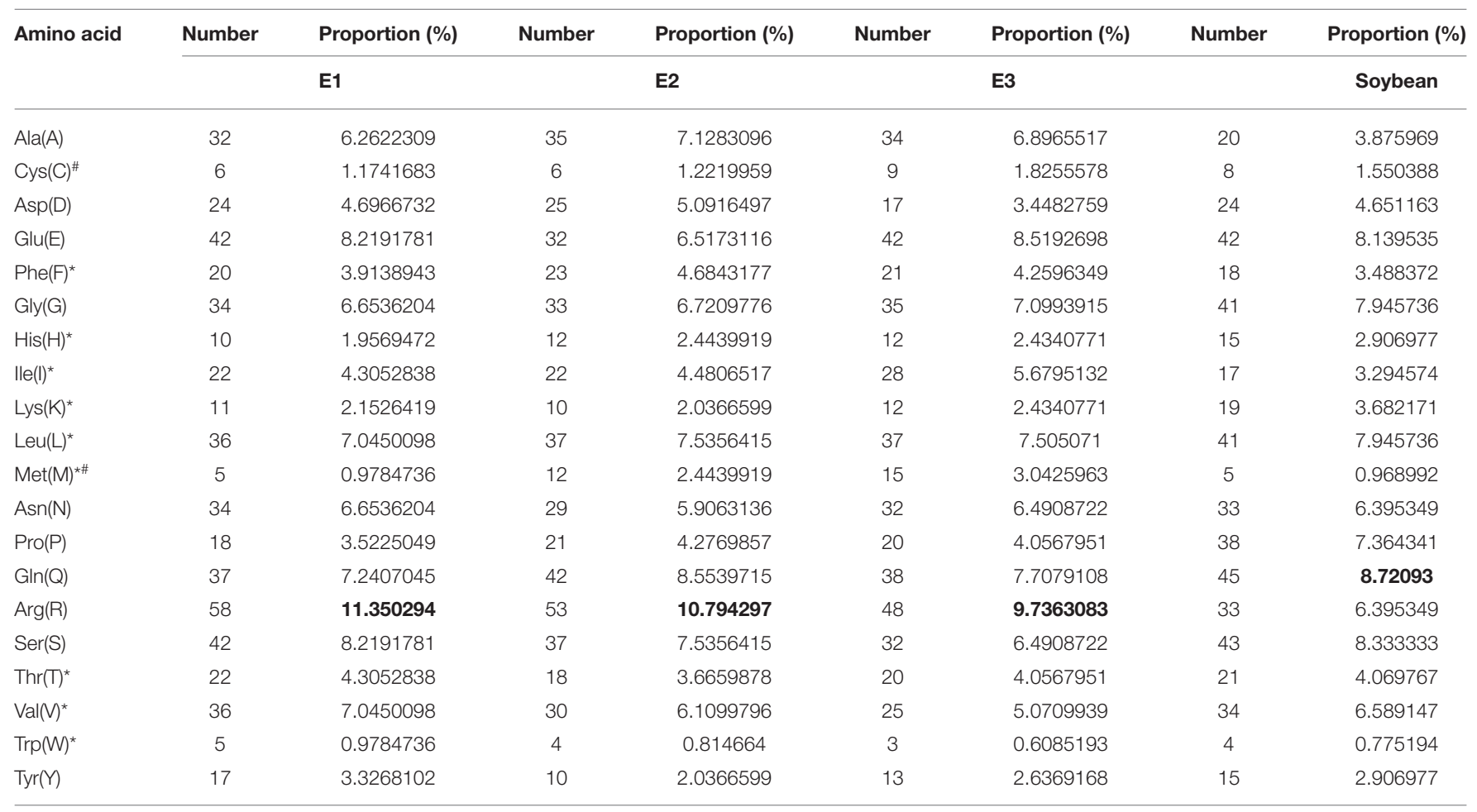

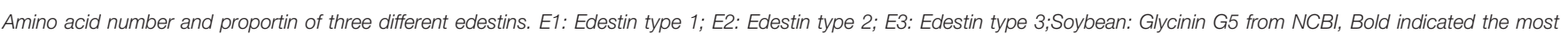
abundant amino acid. *Indicated the essential amino acids. "Indicated the sulfur-containing amino acids.

that observed for Cs7S in the present work (41). The differences in albumin and Cs7S proteins could be related to the plant genotype and growth areas. The hemp cultivar used in Ponzoni's research was Futura, which originated in France and was grown in Italy, and had a THC content of $\sim 0.3 \%$. The cultivar used in McKernan's research was Jamaican Lion which originated in Jamaica and had a THC content of $~ 9 \%$, although it belongs to subspecies sativa. The hemp cultivar used in the present work was Longma 5, which originated in North China and has a THC content lower than $0.3 \%$. According to the results, the genotypes of Futura and Longma 5 might be more similar compared to Jamaican Lion, as the former two have similar THC contents and protein amino acid composition. The seed storage proteins of Longma 5 and Futura have better nutrition value than those of Jamaican Lion, as the former two have a higher ratio of essential amino acids to total amino acids. Therefore, it was inferred that amino acid composition of seed storage proteins varies with the different cultivars of hemp. As stated earlier, the amino acid composition is an important factor affecting the bioactivities and the function of peptides (10), and it could be that the peptides from different hemp cultivars would exhibit different bioactivities and functions. Therefore, it is of great significance to study the different hemp cultivars for developing better bioactive peptides.

The dietary requirements of humans are not for protein per se, but for specific amounts of indispensable or essential amino acids (11). HSP provides all 9 essential amino acids with a balanced amino acid profile, which can be used not only as a nutritive additive but also as a functional ingredient in formulated foods to enhance the product quality attributes. Compared with other plant proteins, HSP has a lower allergenicity, which can be seen as a substitute for other proteins in some food products. Hence, HSP is rising in demand as an alternative source of plant protein. Moreover, HSP is on the path of becoming an important plant protein source in the food and nutraceutical industries, due to its high nutritional and bioactive peptide development values, all of these advances were 
sourced from the various physiological functions of hydrolysates of HSP (6).

\section{CONCLUSION}

The present study extracted the hemp seed storage proteins from the Longma 5 variety grown in North China with different methods, and then characterized them and analyzed the related genes. The results revealed that the modified Osborne method produced the best extraction of the hemp seed storage proteins. Edestins were the most abundant proteins in HSP, and $7 \mathrm{~S}$ vicilin-like protein was the least. Edestins and albumin had a high ratio of Arg/Lys and high content of sulfurcontaining amino acids, which indicated that they had a potential to promote cardiovascular health and serve as a rich thiol source to formulate highly nutritious foods. It also showed that amino acid composition of seed proteins extracted from different hemp cultivars was different, which could be a result of different genotypes. The knowledge of primary structure of these beneficial proteins is an important prerequisite for the development of foods with high nutritional value and identification of bioactive peptide fractions. The present research may, therefore, be viewed as a foundation for future research on the formulation of bioactive products and the development of healthier plant protein sources.

\section{DATA AVAILABILITY STATEMENT}

The original contributions presented in the study are included in the article/Supplementary Material, further inquiries can be directed to the corresponding author.

\section{REFERENCES}

1. Callaway JC. Hempseed as a nutritional resource: an overview. Euphytica. (2004) 140:65-72 doi: 10.1007/s10681-004-4811-6

2. Xu Y, Li J, Zhao J, Wang W, Griffin J, Li Y, et al. Hempseed as a nutritious and healthy human food or animal feed source: a review. Int J Food Sci Tech. (2020) 56:530-43. doi: 10.1111/ijfs.14755

3. Decuyper II, Van Gasse AL, Cop N, Sabato V, Faber MA, Mertens C, et al. Cannabis sativa allergy: looking through the fog. Allergy. (2017) 72:2016. doi: 10.1111/all.13043

4. Schluttenhofer C, Yuan L. Challenges towards revitalizing hemp: a multifaceted crop. Trends Plant Sci. (2017) 22:91729. doi: 10.1016/j.tplants.2017.08.004

5. House JD, Neufeld J, Leson G. Evaluating the quality of protein from hemp seed (Cannabis sativa L.) products through the use of the protein digestibilitycorrected amino acid score method. J Agric Food Chem. (2010) 58:118017. doi: $10.1021 /$ jf102636b

6. Farinon B, Molinari R, Costantini L, Merendino N. The seed of industrial hemp (Cannabis sativa L.): nutritional quality and potential functionality for human health and nutrition. Nutrients. (2020) 12:1935. doi: 10.3390/nu12071935

7. Vainerman ES, Golovina TO, Rogozhin SV. Low-molecular-weight thiol in macromolecules of Canabis sativa 11s globulin-Edestin. Die Nahrung. (1986) 30:398-400. doi: 10.1002/food.19860300355

8. Malomo SA, He R, Aluko RE. Structural and functional properties of hemp seed protein products. J Food Sci. (2014) 79:C151221. doi: 10.1111/1750-3841.12537

9. Pavlovic R, Panseri S, Giupponi L, Leoni V, Citti C, Cattaneo C, et al. Phytochemical and ecological analysis of two varieties of hemp (Cannabis

\section{AUTHOR CONTRIBUTIONS}

XS: conceptualization, methodology, validation, formal analysis, investigation, writing-original draft, and visualization. LW: supervision. QW and YL: resources. YS: formal analysis. All authors contributed to the article and approved the submitted version.

\section{FUNDING}

This work was supported by the funding from Heilongjiang Academy of Sciences, the grant number is YY2020GJS02.

\section{ACKNOWLEDGMENTS}

The authors would like to thank Ms. Mu for providing the hemp seeds.

\section{SUPPLEMENTARY MATERIAL}

The Supplementary Material for this article can be found online at: https://www.frontiersin.org/articles/10.3389/fnut.2021. 678421/full\#supplementary-material

Supplementary Figure 1 | BLAST results of gene coding sequences.

Supplementary Figure 2 | Secondary structure and 3D structure model predictions of hemp seed storage proteins. (A) Secondary predictions of the hemp seed storage proteins. (B) Tertiary structure prediction of the hemp seed storage proteins. All the results were predicted by phyre2.

Supplementary Table 1 | Primer sequences for cloning genes encoding hemp seed storage proteins.

sativa L.) grown in a mountain environment of Italian alps. Front Plant Sci. (2019) 10:1265. doi: 10.3389/fpls.2019.01265

10. Irakli M, Tsaliki E, Kalivas A, Kleisiaris F, Sarrou E, Cook CM. Effect of genotype and growing year on the nutritional, phytochemical, and antioxidant properties of industrial hemp (Cannabis sativa L.) seeds. Antioxidants. (2019) 8:491. doi: $10.3390 /$ antiox8100491

11. Mattila P, Makinen S, Eurola M, Jalava T, Pihlava JM, Hellstrom J, et al. Nutritional value of commercial protein-rich plant products. Plant Foods Hum Nutr. (2018) 73:108-15. doi: 10.1007/s11130-018-0660-7

12. Russo R, Reggiani R. Evaluation of protein concentration, amino acid profile and antinutritional compounds in hempseed meal from dioecious and monoecious varieties. Am J Plant Sci. (2015) 6:14-22. doi: 10.4236/ajps.2015.61003

13. Pojic M, Hadnadev TD, Hadnagev M, Rakita S, Brlek T. Bread supplementation with hemp seed cake: a by-product of hemp oil processing. $J$ Food Qual. (2015) 38:431-40. doi: 10.1111/jfq.12159

14. Wang X-S, Tang C-H, Yang X-Q, Gao W-R. Characterization, amino acid composition and in vitro digestibility of hemp (Cannabis sativa L.) proteins. Food Chem. (2008) 107:11-8. doi: 10.1016/j.foodchem.2007. 06.064

15. Hu JX, Liu M, Jing $\mathrm{X}, \mathrm{Na}$ DQ. Study on toxicological safety of hemp seed proteins. Chin J Health Lab Technol. (2007) 17:2185-90. doi: 10.3969/j.issn.1004-8685.2007.12.023

16. Wu G, Bazer FW, Davis TA, Kim SW, Li P, Rhoads JM, et al. Arginine metabolism and nutrition in growth, health and disease. Amino Acids. (2009) 37:153-68. doi: 10.1007/s00726-008-0210-y

17. Pihlanto A, Mattila P, Makinen S, Pajari AM. Bioactivities of alternative protein sources and their potential health benefits. Food Funct. (2017) 8:344358. doi: 10.1039/C7FO00302A 
18. Mazorra-Manzano MA, Ramirez-Suarez JC, Yada RY. Plant proteases for bioactive peptides release: A review. Crit Rev Food Sci Nutr. (2018) 58:214763. doi: 10.1080/10408398.2017.1308312

19. Raikos V, Duthie G, Ranawana V. Denaturation and oxidative stability of hemp seed (Cannabis sativa L.) protein isolate as affected by heat treatment. Plant Foods Hum Nutr. (2015) 70:304-9. doi: 10.1007/s11130-015-0494-5

20. Wang X-S, Chen L, Yang X-Q. Characterization and antioxidant properties of hemp protein hydrolysates obtained with neutrase. Food Tech Biotech. (2009) 47:428-34. Available online at: http://www.ftb.com.hr/63-volume47-issue-no-4/191-characterization-and-antioxidant-properties-of-hempprotein-hydrolysates-obtained-with-neutrase

21. Aiello G, Lammi C, Boschin G, Zanoni C, Arnoldi A. Exploration of potentially bioactive peptides generated from the enzymatic hydrolysis of hempseed proteins. J Agric Food Chem. (2017) 65:10174-84. doi: 10.1021/acs.jafc.7b03590

22. Saneyasu, T, Shindo, H, Honda, K, Kamisoyama H. The extract of soybean protein increases slow-myosin heavy chain expression in $\mathrm{C} 2 \mathrm{C} 12$ myotubes. $J$ Nutr Sci Vitaminol. (2018) 64:296-300. doi: 10.3177/jnsv.64.296

23. Girgih AT, Alashi AM, He R, Malomo SA, Raj P, Netticadan T, et al. A novel hemp seed meal protein hydrolysate reduces oxidative stress factors in spontaneously hypertensive rats. Nutrients. (2014) 6:565266. doi: 10.3390/nu6125652

24. Girgih AT, He R, Aluko RE. Kinetics and molecular docking studies of the inhibitions of angiotensin converting enzyme and renin activities by hemp seed (Cannabis sativa L.) peptides. J Agric Food Chem. (2014) 62:413544. doi: 10.1021/jf5002606

25. Chakrabarti S, Guha S, Majumder K. Food-derived bioactive peptides in human health: challenges and opportunities. Nutrients. (2018) 10:738. doi: 10.3390/nu10111738

26. Samsamikor M, Mackay D, Mollard RC, Aluko RE. A double-blind, randomized, crossover trial protocol of whole hemp seed protein and hemp seed protein hydrolysate consumption for hypertension. Trials. (2020) 21:354. doi: 10.1186/s13063-020-4164-z

27. Daliri EB, Lee $\mathrm{BH}$, Oh DH. Current trends and perspectives of bioactive peptides. Crit Rev Food Sci Nutr. (2018) 58:227384. doi: 10.1080/10408398.2017.1319795

28. Malomo SA, Onuh JO, Girgih AT, Aluko RE. Structural and antihypertensive properties of enzymatic hemp seed protein hydrolysates. Nutrients. (2015) 7:7616-32. doi: 10.3390/nu7095358

29. Wang R, Huang Y, Wang Z, Jiang Y, Zhong K, Wang J, et al. Research on the immune regulatory function of food derived bioactive peptides. Genomics Appl Biol. (2019) 38:148-52. doi: 10.13417/j.gab.038.000148

30. Potin F, Lubbers S, Husson F, Saurel R. Hemp (Cannabis sativa L.) protein extraction conditions affect extraction yield and protein quality. J Food Sci. (2019) 84:3682-90. doi: 10.1111/1750-3841.14850

31. Rodriguez-Martin NM, Montserrat-de la Paz S, Toscano R, Grao-Cruces E, Villanueva A, Pedroche J, et al. Hemp (Cannabis sativa L.) protein hydrolysates promote anti-inflammatory response in primary human monocytes. Biomolecules. (2020) 10:803. doi: 10.3390/biom10050803

32. Zanoni C, Aiello G, Arnoldi A, Lammi C. Hempseed peptides exert hypocholesterolemic effects with a statin-like mechanism. J Agric Food Chem. (2017) 65:8829-38. doi: 10.1021/acs.jafc.7b02742

33. Girgih AT, Alashi A, He R, Malomo S, Aluko RE. Preventive and treatment effects of a hemp seed (Cannabis sativa L.) meal protein hydrolysate against high blood pressure in spontaneously hypertensive rats. Eur J Nutr. (2014) 53:1237-46. doi: 10.1007/s00394-013-0625-4

34. Malomo SA, Aluko RE. Kinetics of acetylcholinesterase inhibition by hemp seed protein-derived peptides. J Food Biochem. (2019) 43:e12897. doi: 10.1111/jfbc. 12897

35. Girgih AT, Udenigwe, CC, Aluko RE. Reverse-phase HPLC separation of hemp seed (Cannabis sativa L.) protein hydrolysate produced peptide fractions with enhanced antioxidant capacity. Plant Foods Hum Nutr. (2013) 68:39-46. doi: 10.1007/s11130-013-0 340-6

36. The S-S, Bekhit AE-DA, Carne A, Birch J. Antioxidant and ACEinhibitory activities of hemp (Cannabis sativa L.) protein hydrolysates produced by the proteases AFP, HT, Pro-G, actinidin and zingibain. Food Chemistry. (2016) 203:199-206. doi: 10.1016/j.foodchem.2016. 02.057

37. Tang $\mathrm{CH}$, Ten $\mathrm{Z}$, Wang XS, Yang XQ. Physicochemical and functional properties of hemp (Cannabis sativa L.) protein isolate. J Agric Food Chem. (2006) 54:8945-50. doi: 10.1021/jf0619176

38. Ponzoni E, Brambilla IM, Galasso I. Genome-wide identification and organization of seed storage protein genes of Cannabis sativa. Biol Plant. (2018) 62:693-702. doi: 10.1007/s10535-018-0810-7

39. Wang Q, Xiong YL. Processing, nutrition, and functionality of hempseed protein: a review. Compr Rev Food Sci Food Saf. (2019) 18:93652. doi: 10.1111/1541-4337.12450

40. Mamone G, Picariello G, Ramondo A, Nicolai MA, Ferranti P. Production, digestibility and allergenicity of hemp (Cannabis sativa L.) protein isolates. Food Res Int. (2019) 115:562-71. doi: 10.1016/j.foodres.2018. 09.017

41. McKernan KJ, Helbert Y, Kane LT, Ebling H, Zhang L, Liu B, et al. Sequence and annotation of 42 cannabis genomes reveals extensive copy number variation in cannabinoid synthesis and pathogen resistance genes bioRxiv [Preprint]. (2020). doi: 10.1101/2020.01.03.894428

42. $\mathrm{Wu} \mathrm{G}$, Meininger CJ. Regulation of nitric oxide synthesis by dietary factors. Annu Rev Nutr. (2002) 22:6186. doi: 10.1146/annurev.nutr.22.110901.145329

43. Giroux I, Kurowska EM, Freeman DJ, Carroll KK. Addition of arginine but not glycine to lysine plus methionine-enriched diets modulates serum cholesterol and liver phospholipids in rabbits. J Nutr. (1999) 129:180713. doi: $10.1093 / \mathrm{jn} / 129.10 .1807$

44. Docimo T, Caruso I, Ponzoni E, Mattana M, Galasso I. Molecular characterization of edestin gene family in Cannabis sativa L. Plant Physiol Biochem. (2014) 84:142-8. doi: 10.1016/j.plaphy.2014.09.011

Conflict of Interest: The authors declare that the research was conducted in the absence of any commercial or financial relationships that could be construed as a potential conflict of interest.

Copyright (C) 2021 Sun, Sun, Li, Wu and Wang. This is an open-access article distributed under the terms of the Creative Commons Attribution License (CC BY). The use, distribution or reproduction in other forums is permitted, provided the original author(s) and the copyright owner(s) are credited and that the original publication in this journal is cited, in accordance with accepted academic practice. No use, distribution or reproduction is permitted which does not comply with these terms. 